\title{
Moreira, Vital (1997) Auto-Regulação Profissional e Administração Pública, Coimbra: Almedina
}

Joaquim Fidalgo

Como o autor informa logo no início, este livro apresenta dois capítulos da sua tese de doutoramento, defendida na Universidade de Coimbra, em Maio de 1997, e intitulada Auto-Regulação Profissional e Administração Autónoma (A organização institucional do vinho do Porto). Um dos capítulos é genericamente dedicado à “auto-regulação profissional” e outro à “auto-administração profissional”. O interesse desta obra para quem queira debruçar-se sobre as questões globais da regulação - e muito em especial das relações triangulares, neste domínio, entre o Estado, o Mercado e a Sociedade - está na profunda abordagem teórica que Vital Moreira faz aos conceitos em presença e na especificação das diferentes modalidades em que são habitualmente trabalhados. As relações entre auto-regulação e os diferentes tipos de organizações profissionais, os instrumentos auto-regulatórios, a análise comparativa da auto-regulação face à regulação tout court e à desregulação, a articulação entre auto-regulação e sistemas regulatórios, ou entre auto-regulação e formas diversas de corporativismos são, entre muitos, pontos abordados pelo ilustre professor de Direito e constitucionalista. O segundo capítulo dedica-se ao conceito de auto-administração profissional - e, a partir dele, à análise do "variado universo das organizações que compõem a administração autónoma da economia e da vida profissional” (p. 184), tanto em Portugal como em alguns países da União Europeia (França, Alemanha, Itália, Espanha, por exemplo). No estudo sobre os sistemas de regulação das profissões, reflecte-se sobre temas de grande actualidade, como o sentido das corporações profissionais, a história e funções das ordens profissionais ou a sua comparação com as funções dos sindicatos.

Enfatizando a "notável variedade das expressões da auto-administração profissional historicamente realizadas", tal como as foi percorrendo ao longo da sua vasta investigação, Vital Moreira sustenta que elas “não são mais do que espécies de um mesmo género, a saber, a institucionalização oficial do autogoverno profissional de determinadas relações económico-profissionais" (pp. 387-388). E acrescenta: “Da autodisciplina das profissões liberais à autojurisdição das comunidades de regantes, das câmaras de comércio e indústria à auto-administração dos jornalistas portugueses, da auto-regulação dos produtores de leite britânicos à auto-administração dos viticultores dos países do sul da Europa - a ideia de auto-administração económica é hoje

* Professor de Jornalismo na Universidade do Minho e membro do Centro de Estudos de Comunicação e Sociedade (jfidalgo@ics.uminho.pt) 
uma realidade diversificada, multifacetada e presente, em maior ou menor medida, em todos os países" (p. 388). Sendo certo que, como diz ainda Vital Moreira nas conclusões do seu trabalho, "os sistemas regulatórios da economia são, cada vez mais, sistemas mistos, que conjugam em doses diversas elementos de regulação estadual e de auto-regulação publicamente institucionalizada ou reconhecida" (p. 389). 